\title{
FUMONISIN B 1 EXPOSURE INCREASES Hsp70 EXPRESSION IN THE LUNG AND KIDNEY OF RATS WITHOUT INDUCING SIGNIFICANT OXIDATIVE STRESS
}

\author{
Dániel J. Kócsó $^{1 *}$, Judit SzABÓ-FodoR ${ }^{1}$, Miklós MÉzes ${ }^{1,2}$, Krisztián BALOGH $^{2}$, \\ Szilamér FERENCZI ${ }^{3}$, András SZABÓ ${ }^{1,2}$, Brigitta BóTA ${ }^{1}$ and Melinda KovÁCs ${ }^{1,4}$ \\ ${ }^{1}$ MTA-KE Mycotoxins in the Food Chain Research Group, Kaposvár University, \\ Guba S. u. 40, H-7400 Kaposvár, Hungary; ${ }^{2}$ Department of Nutrition, Faculty of \\ Agricultural and Environmental Sciences, Szent István University, Gödöllö, Hungary; \\ ${ }^{3}$ Institute of Experimental Medicine of the Hungarian Academy of Sciences, Budapest, \\ Hungary; ${ }^{4}$ Mycotoxins in the Food Chain Research Group, Faculty of Agricultural \\ and Environmental Sciences, Kaposvár University, Kaposvár, Hungary
}

(Received 13 February 2018; accepted 25 July 2018)

The objective of this experiment was to determine whether fumonisin $B_{1}$ $\left(\mathrm{FB}_{1}\right)$ added to the diet of rats in a dose of $50 \mathrm{mg} / \mathrm{kg}$ changes the production of heat shock protein 70 (Hsp70) in the lungs and kidney of rats. We also studied the effect of this mycotoxin on the antioxidant system of the body. Mature (8 weeks old) male Wistar Crl:WI BR rats ( $\mathrm{n}=6 /$ group) were fed the toxin-containing diet for 5 days. $\mathrm{FB}_{1}$ resulted in a $7 \%$ body weight reduction without significantly changing the feed intake. Western blot analysis of the lungs and kidney demonstrated a substantial (1.4-fold and 1.8-fold, respectively) increase in Hsp70 expression. Alterations could not be detected in the clinical chemical parameters (total protein, albumin, total cholesterol, glucose, creatinine and urea concentrations, and aspartate aminotransferase activity). There was no statistically significant change in malondialdehyde concentrations and the measured antioxidant parameters (the amount of reduced glutathione, GSH and glutathione peroxidase activity, GPx) in the blood plasma, lung and kidney tissue. Thus, it can be concluded that $\mathrm{FB}_{1}$ did not induce oxidative stress in the lungs and kidney, but increased Hsp70 production.

Key words: Fumonisin $B_{1}$, rat, Hsp70, clinical chemical parameters, oxidative stress, antioxidants

*Corresponding author; E-mail: kocso.daniel@ke.hu; gfapgfap@gmail.com; Phone: 0036 (82) 505-800

Open Access. This is an open-access article distributed under the terms of the Creative Commons AttributionNonCommercial 4.0 International License (https://creativecommons.org/licenses/by-nc/4.0/), which permits unrestricted use, distribution, and reproduction in any medium for non-commercial purposes, provided the original author and source are credited, a link to the CC License is provided, and changes - if any - are indicated. 
The mycotoxin fumonisin $\mathrm{B}_{1}\left(\mathrm{FB}_{1}\right)$ is primarily produced by the moulds Fusarium verticillioides and $F$. proliferatum, which are regarded as natural contaminants of maize and maize-based feeds all over the world. $\mathrm{FB}_{1}$ is a polar compound, and the backbone of its structure is a carbon chain containing hydroxyl and methyl groups. $\mathrm{FB}_{1}$ accounts for $70-80 \%$ of the fumonisin analogues (groups A, B, C and P). Due to its structure, it disturbs the biosynthesis of sphingolipid (one of the important membrane constituents) by inhibiting the activity of the sphinganine N-acyltransferase enzyme (Wang et al., 1991; Merrill et al., 1993). As a result of this, one of the toxic effects of $\mathrm{FB}_{1}$ manifests itself in decreasing the amounts of sphingolipids, increasing the levels of the cytotoxic sphinganine ( $\mathrm{Sa}$ ) and sphingosine (So), and inhibiting the degradation processes of sphingolipids (Wang et al., 1991; Yoo et al., 1992; Riley et al., 1994a,b). In addition, $\mathrm{FB}_{1}$ influences the metabolism of phospholipids and polyunsaturated fatty acids, and may induce apoptosis in various tissues (Voss et al., 1996; Tolleson et al., 1996; Bucci et al., 1998). The International Agency for Research on Cancer (IARC) classifies $\mathrm{FB}_{1}$ as a Group $2 \mathrm{~B}$ carcinogen, i.e. it is possibly carcinogenic to humans. It is the direct causative agent of porcine pulmonary oedema (PPE) (Kriek et al., 1981) and equine leukoencephalomalacia (ELEM) (Marasas et al., 1988). Human oesophageal cancer has also been associated with the consumption of maize containing high levels of $\mathrm{FB}_{1}$ (Thiel et al., 1992; Marasas et al., 1993).

Numerous observations have been reported on the renotoxic effects of $\mathrm{FB}_{1}$ depending on the duration of exposure and the magnitude of the doses applied. Such effects include e.g. apoptosis and necrosis, as well as the development of adenoma and carcinoma in which the cytotoxic action of $\mathrm{FB}_{1}$ plays a role. The early experiments conducted by Kriek et al. (1986) on rats suggested that the secondary metabolites of Fusarium moniliforme might induce pathological changes in the renal tissue. This was subsequently confirmed by subchronic (7-30 days) feeding experiments conducted by Voss et al. $(1989,1993)$ with $20-150 \mathrm{mg} / \mathrm{kg}$ $\mathrm{FB}_{1}$, in which histopathological signs indicative of varying degrees of reversible renal toxicity (such as increased tubular basophilia and cytoplasmic vacuolation, hyperplasia of the tubular epithelial cells and their infiltration into the lumen, as well as necrotic processes) were observed. In addition to tubular nephrotic changes, $\mathrm{FB}_{1}$ also caused morphological damage associated among others with hyperplasia in the liver cells and the biliary tract, which was confirmed by the elevated alanine transaminase (ALT), aspartate transaminase (AST) and alkaline phosphatase (ALKP) activities and bilirubin concentration of the blood serum.

During their 26-month-long experiments conducted on rats to reveal the pulmotoxic, hepatotoxic and renotoxic effects of $\mathrm{FB}_{1}$ fed in a concentration of $50 \mathrm{mg} / \mathrm{kg}$, Gelderblom et al. (1991) observed macroscopically visible atrophy in the kidneys. The kidneys had lighter colour and irregular surface, and contained numerous cortical and medullary cysts. Fibrosis, interstitial lymphocytic infiltra- 
tion and the appearance of retention cysts in the kidney were described, together with vacuolar and hyaline degeneration and necrosis of the proximal tubular epithelial cells. Numerous glomerular effects were also noted, such as atrophy of the glomerular bundle, thickening of the glomerular loops, and thickening of the wall of the Bowman's capsule due to fibrotic changes. AST and gammaglutamyl transferase (GGT) activities and (conjugated and unconjugated) bilirubin concentrations were elevated, indicating the hepatotoxic effects of $\mathrm{FB}_{1}$.

After subchronic ( $\leq 90$ days) exposure of rats to $\mathrm{FB}_{1}$-contaminated feed $(0,5,15,50$ and $150 \mathrm{mg} / \mathrm{kg})$, Voss et al. (1996) described mild cellular-level changes in the kidneys and increased apoptotic processes and morphological changes in the cells of proximal tubules located in the area of the so-called corticomedullary junction, on the external side of the medulla. After a single intravenous administration of $\mathrm{FB}_{1}$ to rats in a dose of $1.25 \mathrm{mg} / \mathrm{kg}$, Lim et al. (1996) reported apoptotic and necrotic changes together with cell proliferation processes that could be brought into association with the appearance of the so-called nongenotoxic carcinogenic effects of $\mathrm{FB}_{1}$. By histological examination of the kidneys of rats fed increasing doses $\left(99,163,234\right.$ and $484 \mathrm{mg} / \mathrm{kg}$ ) of $\mathrm{FB}_{1}$ for 28 days, Tolleson et al. (1996) demonstrated an increase in the apoptotic processes of tubular epithelial cells.

In a 104-week dose-response feeding study, $\mathrm{FB}_{1}$ did not prove to be carcinogenic in female F344/N/Nctr BR rats even in a dose as high as $100 \mathrm{mg} / \mathrm{kg}$ feed, while in male rats dietary $\mathrm{FB}_{1}$ concentrations of 50 and $150 \mathrm{mg} / \mathrm{kg}$ induced adenoma and carcinoma involving the renal tubules (Howard et al., 2001).

Much less information is available on the effects of $\mathrm{FB}_{1}$ on the pulmonary tissues of rats. Gelderblom et al. (1991) fed BD IX male rats a diet containing $50 \mathrm{mg} / \mathrm{kg}$ purified $\mathrm{FB}_{1}$ for 26 months. In $66 \%$ of the rats examined between the 18 th and the 26th month of the study hepatocellular carcinoma was found, which produced metastases to the lungs, heart and kidneys.

In their 5-day experiments, He et al. (2002) administered $\mathrm{FB}_{1}$ subcutaneously to mice in a dose of $2.25 \mathrm{mg} / \mathrm{kg}$ body weight. They found increased tumour necrosis factor alpha (TNF $\alpha)$ mRNA expression and elevated levels of the sphingoid bases (sphingosine and sphinganine), which was different in the lungs and the heart. After the intraperitoneal injection of $\mathrm{FB}_{1}$ to mice in a dose of $10 \mathrm{mg} / \mathrm{kg}$ body weight over a period of 5 days, Kim et al. (2006) observed significant elevations in the levels of Sa and Sa-1-P in the lung, kidney, liver, heart and brain tissues, without any pathological changes in the tissues. The apoptotic and pathological changes attributable to the presence of mycotoxins trigger cytoprotective molecular processes associated with the increased production of heat shock proteins (Jolly and Morimoto, 2000; Hassen et al., 2005). Heat shock proteins constitute the most ancient and evolutionarily extremely well conserved intracellular defence system of eukaryotic cells. They are present in the cytoplasm, nucleus and mitochondria, and one of their main tasks is to protect proteins against harmful effects (e.g. oxidative 
stress). Their increased expression can be an early marker of cytotoxic effects. Studying the relationship between oxidative stress caused by mycotoxins and Hsp70 production, El Golli-Bennour and Bacha (2011) classified fumonisins as mycotoxins having a moderate oxidative effect. However, there is a scarcity of data on the effect of $\mathrm{FB}_{1}$ on Hsp production, and most of the available data were derived from in vitro experiments performed in cell cultures.

Therefore, the aim of this work was to study the acute effects of $\mathrm{FB}_{1}$ administered in a dose of $50 \mathrm{mg} / \mathrm{kg}$ of diet for 5 days, focusing on oxidative stress and the production of heat shock protein 70 (Hsp70) in hitherto less investigated organs, the lungs and the kidney.

\section{Materials and methods}

\section{Accommodation and feeding of rats, sampling}

Mature (8 weeks old) male Wistar Crl:WI BR rats weighing approximately 200-250 g ( $\mathrm{n}=6$ /group, $\mathrm{FB}_{1}$ vs. control, total $\left.\mathrm{n}=12\right)$ and kept in individual metabolic cages (Tecniplast, Castronno, Italy) were used in the experiments. In the experimental room, light (8:00-20:00) and dark (20:00-8:00) periods were alternated at 12 -h intervals daily (at $20^{\circ} \mathrm{C}$ and $50 \%$ relative humidity). The commercial diet (Ssniff, $\mathrm{R} / \mathrm{M}-\mathrm{Z}+\mathrm{H}$ ) was ground, and an $\mathrm{FB}_{1}$-containing fungal culture was added to it to provide a finished feed containing $50 \mathrm{mg} / \mathrm{kg} \mathrm{FB}$ for the experimental group. After homogenisation, the ground diet was regranulated and then dried at $40{ }^{\circ} \mathrm{C}$. The diet fed to the control group was also ground and then regranulated, but no fungal culture was added to it. During the experiment, drinking water and feed were provided ad libitum, the daily feed intake was recorded, and the body weights of the rats were measured at the start and at the end of the experiment. After the treatments lasting for 5 days, blood samples were taken from the retroorbital plexus of the rats in diethyl ether narcosis, then the rats were decapitated and exsanguinated after cervical dislocation for postmortem sample collection. To determine Hsp70 expression, approximately $0.5 \mathrm{-g}$ samples were taken from the lungs and the kidneys of all rats, from the same anatomical locations, and the samples were stored at $-80^{\circ} \mathrm{C}$ until analysed. Blood serum samples were assayed for clinical chemical parameters while lung and kidney samples for parameters indicative of oxidative stress.

The animal experiment was authorised by the Food Chain Safety and Animal Health Directorate of Somogy County Government Office under permission no. SOI/31/1679-11/2014.

\section{Production of $F B_{I}$}

Fumonisin $\mathrm{B}_{1}$ was produced by the application of Fusarium verticillioides strain MRC 826 according to the method of Fodor et al. (2008). The homoge- 
nised fungal culture contained $\mathrm{FB}_{1}$ at a concentration of $3.44 \mathrm{~g} / \mathrm{kg}$. This fungal culture was mixed into the basal diet of the experimental animals, to provide feed contaminated with $50 \mathrm{mg} / \mathrm{kg} \mathrm{FB}$ toxin. The mycotoxin concentrations of the control and the experimental diets were determined by LC-MS (Shimadzu, Kyoto, Japan). The lower limit of detection (LOD) for $\mathrm{FB}_{1}$ was $3 \mu \mathrm{g} / \mathrm{kg}$. The diet fed to the control group did not contain detectable amounts of $\mathrm{FB}_{1}$. The absence of deoxynivalenol, zearalenone and T-2 toxin was checked and confirmed.

\section{Western blot analysis}

Kidney and lung tissue samples ( $\mathrm{n}=6$ /group) were homogenised in $500 \mu 1$ lysis buffer (1\% NP40, $1 \%$ sodium deoxycholate, $0.1 \%$ SDS, $15 \mathrm{mM} \mathrm{NaCl}$, $10 \mathrm{mM}$ phosphate buffer, $2 \mathrm{mM}$ EDTA, $2 \mathrm{mg} / \mathrm{ml}$ aprotinin, $0.5 \mathrm{mg} / \mathrm{ml}$ leupeptin, $2 \mathrm{mM}$ sodium vanadate, $20 \mathrm{mM} \mathrm{NaF}, 0.5 \mathrm{mM}$ DTT, $1 \mathrm{mM}$ PMSF) for $3 \mathrm{~min}$. Subsequently the cell lysate was centrifuged $\left(13,000 \mathrm{rpm}, 30 \mathrm{~min}, 4^{\circ} \mathrm{C}\right)$ and the pellet collected. Total protein concentration of the samples was determined with the BCA ${ }^{\mathrm{TM}}$ Protein Assay KIT (Thermo-Fisher, Budapest, Hungary). Thirty to $35 \mu \mathrm{g}$ protein/sample quantities were applied to $10 \%$ SDS polyacrylamide gels [30\% Acrylamide/Bis-acrylamide, $1.5 \mathrm{M}$ Tris $(\mathrm{pH} 8.8), 1.0 \mathrm{M}$ Tris $(\mathrm{pH} 6.8)$, $100 \mathrm{~g} / \mathrm{L}$ SDS, $100 \mathrm{~g} / \mathrm{L}$ APS, TEMED] and transferred to nitrocellulose $(0.45 \mu \mathrm{m})$ membranes. The membranes were washed for $3 \times 5$ minutes with TBS-T $(1 \times$ TBS $\mathrm{pH} 7.6,0.1 \%$ Tween 20$)$, then blocked in phosphate-buffered saline (10× PBS) containing $5 \%$ nonfat dried milk powder, $1 \%$ BSA and $0.1 \%$ Tween 20 . Subsequently the membranes were incubated with primary anti-Hsp70 antibodies (1:1000; Sigma, Budapest) at $4{ }^{\circ} \mathrm{C}$ for $12 \mathrm{~h}$. As internal control, anti- $\beta$ actin antibodies (1:10,000; Sigma, Budapest, Hungary) were used. After another $3 \times 5$-min washing with TBS-T $(\mathrm{pH} 7.5)$, secondary antibodies conjugated with horseradish peroxidase (HRP) were used in 1:500 dilution (Biomarker, Budapest, Hungary) to quantify the binding of the primary antibodies. After a repeated $3 \times 5$-min washing with TBS-T, the light emission of the blotted proteins was ensured by the use of a WesternBright Enhanced Chemiluminescent HRP substrate detection system (Biomedica, Budapest, Hungary), and the proteins were detected either on CL-XPosure clear-blue X-ray films or using a FluorChem Q Imaging system imaging program (ProteinSimple, Santa Clara, CA, USA). The densitometric analysis of the chemiluminescent signals thus obtained was performed with an ImageJ software. The data were presented by pixel density in arbitrary units \pm SEM $(\mathrm{P}<0.05)$.

\section{Clinical chemistry and antioxidant parameters}

The concentrations of plasma total protein (TP), albumin (ALB), total cholesterol (tCHOL), glucose (GLU), creatinine (CREA) and urea, as well as the activities of aspartate aminotransferase (AST), were determined in a veterinary la- 
boratory (Vet-Med Laboratory Ltd., Budapest, Hungary), using a Roche Hitachi 912 Chemistry Analyzer (Hitachi, Tokyo, Japan) with commercial diagnostic kits (Diagnosticum Ltd., Budapest, Hungary).

For the determination of lipid peroxidation, blood plasma, kidney and lung samples were stored at $-80{ }^{\circ} \mathrm{C}$ until analysed. Lipid peroxidation was determined by the quantification of malondialdehyde (MDA) levels by the 2-thiobarbituric acid method (Placer et al., 1966) in the blood plasma and in 1:9 homogenates of tissue samples in physiological saline. Among the components of the antioxidant system, the amount of reduced glutathione (GSH) measured in the blood plasma and $10,000 \mathrm{~g}$ supernatant fraction of tissue homogenates by the method of Sedlak and Lindsay (1968) and the activity of glutathione peroxidase (GPx) according to Lawrence and Burk (1978). GSH content and GPx activity were calculated to protein content which was determined by the biuret method in the blood plasma (Weichselbaum, 1948) and with Folin phenol reagent in tissue homogenates (Lowry et al., 1951).

\section{Statistical analysis}

For the comparison of group means (body weight, Hsp70, antioxidant parameters, clinical chemical parameters), unpaired $t$-test was used with the GraphPad Prism 7.00 software. Normality was tested with GraphPad Prism 7.00 according to the Kolmogorov-Smirnov method.

\section{Results}

\section{Body weight}

Although the difference was not significant, the average initial body weight of the toxin-treated animals was slightly higher compared to controls (Table 1). During the 5-day-long feeding the control group showed a body weight gain while the FB1 group a body weight decrease. The weekly average feed intake was not significantly different in the two groups. However, the daily feed intake data show that the toxin-fed rats consumed less feed from the second day of the experiment onwards, although the difference was significant only on day 4 (Table 2).

\section{Western blot analysis}

By Western blot analysis we determined the changes in the quantity of Hsp70 protein in the lung and kidney tissues of the rats treated with $\mathrm{FB}_{1}$ (Fig. 1).

During the five-day $\mathrm{FB}_{1}$ feeding trials the Hsp70 (iHsp70, Hsp72) protein expression of the rat lung significantly increased as compared to the lung tissue of the control rats (Fig. 1a). Also, there was a significant difference between the 
toxin-fed and the control rats in the quantitative changes of inducible Hsp70 (iHsp70) in the kidney tissue as a result of the 5-day treatment (Fig. 1b).

\section{Table 1}

Somatic traits of the control group and the group fed fumonisin $B_{1}($ mean $\pm S E M, n=6$ per group)

\begin{tabular}{lccc}
\hline Somatic traits & Control & Fumonisin $\mathrm{B}_{1}$ & $\mathrm{P}(t$-test $)$ \\
\hline Daily feed consumption, $\mathrm{g}$ & $14.1 \pm 1.6$ & $13.0 \pm 0.5$ & $\mathrm{NS}$ \\
Initial body weight, $\mathrm{g}$ & $210.4 \pm 12.4$ & $242.3 \pm 10.0$ & $\mathrm{NS}$ \\
Final body weight, $\mathrm{g}$ & $217.3 \pm 13.1$ & $223.7 \pm 23.0$ & $\mathrm{NS}$ \\
Weight gain, g/5 days & $6.92 \pm 2.55$ & $-18.6 \pm 7.6$ & 0.007 \\
\hline
\end{tabular}

$\mathrm{NS}=$ not significant

Table 2

Daily feed intake (g/day/animal) of the control group and the group fed fumonisin $\mathrm{B}_{1}$ (mean $\pm \mathrm{SEM}, \mathrm{n}=6$ per group)

\begin{tabular}{lccc}
\hline Day & Control & Fumonisin $\mathrm{B}_{1}$ & $\mathrm{P}(t$-test $)$ \\
\hline Day 1 & $14.6 \pm 2.9$ & $17.7 \pm 4.1$ & $\mathrm{NS}$ \\
Day 2 & $14.6 \pm 3.3$ & $12.0 \pm 2.4$ & $\mathrm{NS}$ \\
Day 3 & $14.5 \pm 3.8$ & $11.9 \pm 1.8$ & $\mathrm{NS}$ \\
Day 4 & $14.2 \pm 1.1$ & $12.4 \pm 1.5$ & 0.04 \\
Day 5 & $14.2 \pm 2.3$ & $11.7 \pm 2.5$ & $\mathrm{NS}$ \\
\hline
\end{tabular}

$\mathrm{NS}=$ not significant

\section{Peroxidation and antioxidant parameters}

No statistically significant differences were found in MDA concentrations and in the measured antioxidant parameters (GSH, GPx) of the blood plasma, lung and kidney in the treated and in the control groups (Table 3).

\section{Clinical chemical parameters}

There were no statistically significant differences in the clinical chemical parameters, which were in the reference range, indicating that $\mathrm{FB}_{1}$ administered in this dose for such a short period of time did not cause serious pathological alterations in kidney and liver function (Table 4).

\section{Discussion}

Considering the animals' body weight and feed intake, the $50 \mathrm{mg} / \mathrm{kg}$ of feed $\mathrm{FB}_{1}$ dose was equivalent with about $3 \mathrm{mg} / \mathrm{kg}$ of body weight (bwkg) oral $\mathrm{FB}_{1}$ exposure. Taking into account the low absorption rate of $\mathrm{FB}_{1}$ (about $4 \%$ ), this corresponded to about $0.12 \mathrm{mg} / \mathrm{bwkg}$ parenteral toxin intake. 
(a)
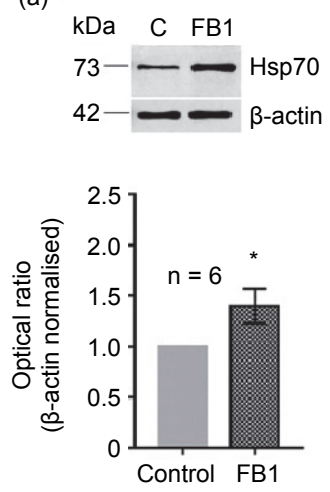

(b)
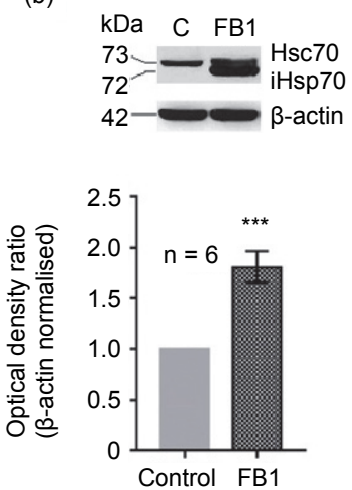

Fig. 1. Changes of Hsp70 protein expression induced by fumonisin $\mathrm{B}_{1}$ treatment. The pictures above the diagrams represent the characteristic electrophoretic profiles of proteins isolated from the lungs (a) and the kidney (b). The band of $\beta$-actin as normalisation control (42 kDa) can be seen in the lower rows, under the bands of the Hsp70 (constitutive Hsp70) and iHsp70 (inducible Hsp70) proteins. The constitutive Hsp proteins can be seen in the $\sim 73 \mathrm{kDa}$ band of the upper row, while the inducible Hsp variants in the lower, $\sim 72 \mathrm{kDa}$ row (Hsp72). As a result of $\mathrm{FB}_{1}$ treatment, the quantity of Hsp70 increased significantly in both the lungs (a) and the kidney (b). Data are presented as mean \pm SEM. ${ }^{* * *} \mathrm{P}<0.001$ and ${ }^{*} \mathrm{P}<0.05$

$\mathrm{FB}_{1}$ did not induce expressed feed refusal but resulted in significant body weight loss. In a study using rats, the oral intake of $88.6 \mathrm{mg} / \mathrm{kg} \mathrm{FB} \mathrm{FB}_{1}$ (as fungal culture) over a period of 10 days did not cause weight loss or reduced feed intake (Riley and Voss, 2006); however, the mean body weight and feed consumption was 10 and $20 \%$ lower, respectively, compared to the control group (the difference was not significant). The intake of $>10 \mathrm{mg} / \mathrm{kg} \mathrm{FB}$ in feed $(0.82 \mathrm{mg} / \mathrm{bwkg})$ lowered the growth performance of rats after 35 days because of impaired feed utilisation (Gbore et al., 2010). According to Gelderblom et al. (1994), FB 1 reduces the feed intake in the first 14 days of exposure but subsequently this effect disappears as a result of adaptation at high $(250,500$ and $750 \mathrm{mg} / \mathrm{kg}$ diet $)$ levels of $\mathrm{FB}_{1}$. Considering the above findings, it is a novel result that $\mathrm{FB}_{1}$ fed in a dose of $50 \mathrm{mg} / \mathrm{kg}$ of diet reduced the body weight by about $7 \%$ within 5 days. Taking the feed intake data into consideration, the body weight loss was presumably not only attributable to less feed consumption, but also to the impaired digestibility of nutrients as shown by Gbore et al. (2010). As that was the only study related to $\mathrm{FB}_{1}$ and feed utilisation, further investigations are needed to support these results.

The cell-level mechanism of action of $\mathrm{FB}_{1}$ is not known in every detail even today. With respect to its effects exerted on phospholipids, the constituents of cell membranes, its structural analogy with sphingoid bases serving as the backbone of sphingolipids is of decisive importance. Phospholipids play a fun- 
damental role in cellular signal transduction processes, cell proliferation and differentiation, as well as in apoptosis (Merrill et al., 1997).

\section{Table 3}

Malondialdehyde concentration and antioxidant parameters in the blood plasma, lung and kidney tissue of the control rats and the rats fed fumonisin $\mathrm{B}_{1}$ (mean $\pm \mathrm{SEM}, \mathrm{n}=6$ per group)

\begin{tabular}{lrr}
\hline Parameters & \multicolumn{1}{c}{ Control } & Fumonisin $\mathrm{B}_{1}$ \\
\hline \multicolumn{3}{c}{ Plasma } \\
\cline { 2 - 3 } $\mathrm{GSH}^{1}$ & $2.82 \pm 0.08$ & $2.89 \pm 0.09$ \\
$\mathrm{GPx}^{2}$ & $2.82 \pm 0.35$ & $3.30 \pm 0.13$ \\
MDA $^{3}$ & $33.79 \pm 1.02$ & $36.61 \pm 3.09$ \\
\hline \multicolumn{3}{c}{ Lung } \\
GSH & $2.67 \pm 0.14$ & $3.04 \pm 0.34$ \\
GPx & $2.58 \pm 0.32$ & $3.10 \pm 0.38$ \\
MDA & $92.58 \pm 9.92$ & $106.40 \pm 8.14$ \\
\hline \multicolumn{3}{c}{ Kidney } \\
GSH & $1.87 \pm 0.11$ & $2.09 \pm 0.08$ \\
GPx & $0.77 \pm 0.04$ & $0.79 \pm 0.082$ \\
MDA & $109.60 \pm 6.16$ & $89.30 \pm 4.02$ \\
\hline
\end{tabular}

${ }^{1}$ glutathione (micromoles/g protein), ${ }^{2}$ glutathione peroxidase (IU/g protein), ${ }^{3}$ malondialdehyde (micromoles/g)

Table 4

Clinical chemical parameters of the control rats and the rats fed fumonisin $B_{1}$ (mean $\pm S E M, n=6$ per group)

\begin{tabular}{lrcc}
\hline Clinical chemical parameters & \multicolumn{1}{c}{ Control } & Fumonisin $\mathrm{B}_{1}$ & $\mathrm{P}$ \\
\hline Albumin $(\mathrm{g} / \mathrm{l})$ & $35.53 \pm 0.32$ & $34.48 \pm 0.55$ & 0.367 \\
AST $(\mathrm{IU} / \mathrm{l})$ & $123.30 \pm 8.12$ & $118.2 \pm 10.94$ & 0.818 \\
Glucose $(\mathrm{mmol} / \mathrm{l})$ & $5.26 \pm 0.75$ & $4.967 \pm 0.5$ & 0.335 \\
Urea $(\mathrm{mmol} / \mathrm{l})$ & $4.98 \pm 0.51$ & $7.6 \pm 2.99$ & 0.08 \\
Creatinine $(\mu \mathrm{mol} / \mathrm{l})$ & $39.00 \pm 1.91$ & $45 \pm 4.06$ & 0.325 \\
Total cholesterol $(\mathrm{mmol} / \mathrm{l})$ & $1.28 \pm 0.11$ & $1.367 \pm 0.14$ & 0.489 \\
Total protein $(\mathrm{g} / \mathrm{l})$ & $64.98 \pm 0.93$ & $63.2 \pm 1.46$ & 0.788 \\
\hline
\end{tabular}

Acting as a competitive inhibitor of N-acyltransferase (ceramide synthase), FB1 decreases the amount of complex sphingolipids (Zieglerheitbrock et al., 1992; Wood et al., 1992), which may manifest itself in the accumulation of sphingoid bases and their metabolites, the disturbances of cell proliferation and differentiation, and in increased apoptosis (Harel and Futerman, 1993; Schroeder et al., 1994; Yoo et al., 1996). TNF- $\alpha$ signalling as one of the messenger systems trig- 
gering apoptosis (Wallach, 1996) forms part of the cytotoxicity of $\mathrm{FB}_{1}$ (Yoo et al., 1996). The binding of TNF $\alpha$ to appropriate death receptors (DR) may stimulate extrinsic, primarily non-oxidative signalling, as pathways leading to apoptosis (Mahmood and Shukla, 2010). Numerous aspects of the role played by oxidative stress in the cytotoxicity of $\mathrm{FB}_{1}$ and in the cause and effect relationships involved are still unclear. As in the present experiment we did not find significant changes in the antioxidant parameters either in the kidney or in the lungs, it is likely that the stimulus triggering the increased synthesis of heat shock proteins was some factor not affecting the mitochondrial respiratory chain. All these are consistent with earlier statements according to which $\mathrm{FB}_{1}$ belongs to the moderately oxidative toxins (Galvano et al., 2002; Mobio et al., 2003; Domijan and Abramov, 2011).

Abel and Gelderblom (1998) as well as Lemmer et al. (1999) described lipid peroxidation as a later step of cytotoxicity than the primary damage caused by $\mathrm{FB}_{1}$. This is also supported by the fact that Marnewick et al. (2009) found increased GPx activity in the kidney of rats, but only after exposure to a high $\mathrm{FB}_{1}$ dose ( $250 \mathrm{mg} / \mathrm{kg}$ of feed) fed for 21 days.

Despite the DNA damage caused by $\mathrm{FB}_{1}$, Galvano et al. (2002) did not observe a significant increase either in reactive oxygen species (ROS) production or in cytotoxicity and extracellular lactate dehydrogenase (LDH) activity.

We consider it possible that $\mathrm{FB}_{1}$ exposure affected the mitochondria but the applied dose and exposure time did not cause sufficient damage in the mitochondrial membranes to allow the release of cytochrome $\mathrm{c}$ and other apoptogenic factors into the cytoplasm.

To confirm either of these alternatives, it would be necessary to demonstrate the presence or absence of other 'helper' proteins or different components of the signalling pathways associated with oxidative damage. It is also possible that $\mathrm{FB}_{1}$ activated that molecular mechanism of the so-called extrinsic apoptotic signal transduction which, by avoiding the mitochondria and thus ROS release, amplified the activation of caspase- 8 (from the elements of the caspase cascade), thus triggering an alternative signalling mechanism leading to apoptosis (Jones et al., 2001), and the amount of Hsp70 may have increased when all these events were blocked.

On the basis of our results we can state that dietary exposure of rats to $50 \mathrm{ppm} \mathrm{FB}_{1}$ for 5 days led to an increase in the quantity of Hsp70, which presumably indicates alteration of the physiological signal transduction processes taking place in the kidney and lungs and augmentation of the cytoprotective mechanisms, though this assumption has to be supported by additional investigations.

The molecular mechanisms utilised by different xenobiotics such as $\mathrm{FB}_{1}$, leading to the increase of Hsp70 expression, are associated with structural modifications of cellular proteins induced by toxin treatment (Salminen et al., 1996, 
1998). The activity increase found during the relatively short, 5-day mycotoxin treatment used in this study is not surprising, as the physiological synthetic processes tend to change already within a few hours after harmful stress effects exerted on cells, and they may remain inhibited for several days (Rao and Engelberg, 1965). Parallel to all these changes, the quantity of stress proteins also increases, and the degree and duration of the stress effect influence the intensity and duration of the stress response.

During exposure to different environmental stressors, the protein aggregates and/or denatured proteins accumulating in the cytosol activate the heat shock transcription factor (HSF) through heat shock factor type 1, and this may be one of the initial steps of the developing stress response. After its trimerisation, phosphorylated HSF-1 becomes capable of migrating into the cell nucleus and, through stimulation of the promoter region of the heat shock components, inducing Hsp gene expression (Otaka et al., 2006). Although after the intraperitoneal treatment of rats with $0.5 \mathrm{mg} / \mathrm{kg} \mathrm{FB}$ for 2-7 days, Rumora et al. (2007) measured lower-intensity Hsp70 activity in the kidneys, suggesting the inhibitory effect exerted by $\mathrm{FB}_{1}$ on HSF-1 as a possible reason. Based upon the heat shock response (HSR) given to the treatment applied in the present experiment, it can be assumed that some other molecular mechanisms may underlie this enhanced expression.

Under the present experimental conditions $\left(50 \mathrm{mg} / \mathrm{kg}\right.$ feed $\mathrm{FB}_{1}$ oral exposure for 5 days) the actual intensity of the molecular chaperon network could be affected. In order to get a more accurate picture on the underlying mechanisms responsible for the different Hsp expressions, we need further investigations to reveal other factors involved in the cellular defence system.

\section{Acknowledgements}

This research was supported by the Hungarian Academy of Sciences (within the framework of the MTA-KE 'Mycotoxins in the Food Chain' Research Group), the GINOP Excellence program ref. no.: GINOP-2.3.2-15-2016-00046 and the EFOP-3.6.3VEKOP-16-2017-00008 project. The authors thank Dr. Viktória Dénes (Department of Experimental Zoology and Neurobiology, Institute of Biology, Faculty of Sciences, Pécs University) for her help in evaluating the results of the Western blot analysis.

\section{References}

Abel, S. and Gelderblom, W. C. (1998): Oxidative damage and fumonisin $\mathrm{B}_{1}$-induced toxicity in primary rat hepatocytes and rat liver in vivo. Toxicology 131, 121-131.

Bucci, T. J., Howard, P. C., Tolleson, W. H., Laborde, J. B. and Hansen, D. K. (1998): Renal effects of fumonisin mycotoxins in animals. Toxicol. Pathol. 26, 160-164. 
Domijan, A-M. and Abramov, A. Y. (2011): Fumonisin $B_{1}$ inhibits mitochondrial respiration and deregulates calcium homeostasis - Implication to mechanism of cell toxicity. Int. J. Biochem. Cell Biol. 43, 897-904.

El Golli-Bennour, E. and Bacha, H. (2011): Hsp70 expression as biomarkers of oxidative stress: Mycotoxins' exploration. Toxicology 287, 1-7.

Fodor, J., Balogh, K., Weber, M., Mézes, M., Kametler, L., Pósa, R., Mamet, R., Bauer, J., Horn, P., Kovács, F. and Kovács, M. (2008): Absorption, distribution and elimination of fumonisin $\mathrm{B}_{1}$ metabolites in weaned piglets. Food Addit. Contam. Part A 25, 88-96.

Galvano, F., Campisi, A., Russo, A., Galvano, G., Palumbo, M., Renis, M., Barcellona, M. L., Perez-Polo, J. R. and Vanella, A. (2002): DNA damage in astrocytes exposed to fumonisin $\mathrm{B}_{1}$. Neurochem. Res. 27, 345-351.

Gbore, F. A., Yinusa, R. I. and Salleh, B. (2010): Evaluation of subchronic dietary fumonisin $\mathrm{B}_{1}$ on nutrient digestibility and growth performance of rats. Afr. J. Biotechnol. 9, 6442-6447.

Gelderblom, W. C., Cawood, M. E., Snyman, S. D. and Marasas, W. F. (1994): Fumonisin B ${ }_{1}$ dosimetry in relation to cancer initiation in rat liver. Carcinogenesis 15, 209-214.

Gelderblom, W. C., Kriek, N. P. J., Marasas, W. F. O. and Thiel, P. G. (1991): Toxicity and carcinogenicity of the Fusarium moniliforme metabolite, fumonisin $\mathrm{B}_{1}$, in rats. Carcinogenesis 12, 1247-1251.

Harel, R. and Futerman, A. H. (1993): Inhibition of sphingolipid synthesis affects axonal outgrowth in cultured hippocampal neurons. J. Biol. Chem. 268, 14476-14481.

Hassen, W., El Golli, E., Baudrimont, I., Mobio, T. A., Ladjimi, M., Creppy, E. E. and Bacha, H. (2005): Cytotoxicity and Hsp70 induction in Hep G2 cells in response to zearalenone and cytoprotection by sub-lethal heat shock. Toxicology 207, 293-301.

He, Q., Bhandari, N. and Sharma, R. P. (2002): Fumonisin $B_{1}$ alters sphingolipid metabolism and tumor necrosis factor alpha expression in heart and lung of mice. Life Sci. 71, 2015-2023.

Howard, P. C., Eppley, R. M., Stack, M. A., Warbritton, A., Voss, K. A., Lorentzen, R. J., Kovach, R. M. and Bucci, T. J. (2001): Fumonisin $B_{1}$ carcinogenicity in a two-year feeding study using F344 rats and B6C3F1 mice. Environ. Health Perspect. 109, 277-282.

Jolly, C. and Morimoto, R. (2000): Role of the heat shock response and molecular chaperones in oncogenesis and cell death. J. Natl Cancer Inst. 92, 1564-1572.

Jones, C., Ciacci-Zanella, J. R., Zhang, Y., Henderson, G. and Dickman, M. (2001): Analysis of fumonisin B1-induced apoptosis. Environ. Health Perspect. 109, 315-320.

Kim, D. H., Yoo, H. S., Lee, Y. M., Kie, J. H., Jang, S. and Oh, S. (2006): Elevation of sphinganine 1-phosphate as a predictive biomarker for fumonisin exposure and toxicity in mice. J. Toxicol. Environ. Health 69, 2071-2082.

Kriek, N. P. J., Kellerman, T. S. and Marasas, W. F. O. (1981): A comparative study of the toxicity of Fusarium verticillioides ( $F$. moniliforme) to horses, primates, pigs, sheep and rats. Onderstepoort J. Vet. Res. 48, 129-131.

Kriek, N. P. J., Marasas, W. F. O., van Rensburg, S. J., Finchem, J. E., Yagen, B. and Joffe, A. Z. (1986): Chronic pathological effects of some fusarial toxins. In: Steyn, P. S. and Vleggaar, R. (eds) Mycotoxins and Phycotoxins. Elsevier, Amsterdam. pp. 525-534.

Lawrence, R. A. and Burk, R. F. (1978): Species, tissue and subcellular distribution of non Sedependent glutathione peroxidase activity. J. Nutr. 108, 211-215.

Lemmer, E. R., de la Motte-Hall, P., Omori, N., Omori, M., Shephard, E. G., Gelderblom, W. C. A., Cruse, J. P., Barnard, R. A., Marasas, F. O., Kirsch, R. E. and Thorgeirsson, S. S. (1999): Histopathology and gene expression changes in rat liver during feeding of fumonisin $\mathrm{B}_{1}$, a carcinogenic mycotoxin produced by Fusarium moniliforme. Carcinogenesis 20, 817-824.

Lim, C. W., Parker, H. M., Vesonder, R. F. and Haschek, W. M. (1996): Intravenous fumonisin B1 induces cell proliferation and apoptosis in the rat. Natural Toxins 4, 34-41.

Lowry, O. H., Rosenbrough, N. J., Farr, A. L. and Randall, R. J. (1951): Protein measurement with the Folin phenol reagent. J. Biol. Chem. 193, 265-275. 
Mahmood, Z. and Shukla, Y. (2010): Death receptors: targets for cancer therapy. Exp. Cell Res. 316, 887-899.

Marasas, W. F. O., Kellerman, T. S., Gelderblom, W. C. A., Coetzer, J. A. W., Thiel, P. G. and van der Lugt, J. J. (1988): Leukoencephalomalacia in a horse induced by fumonisin $\mathrm{B}_{1}$ isolated from Fusarium moniliforme. Onderstepoort J. Vet. Res. 55, 197-203.

Marasas, W. F. O., Thiel, P. G., Gelderblom, W. C. A., Shephard, G. S., Sydenham, G. S. and Rheeder, J. P. (1993): Fumonisins produced by Fusarium moniliforme in maize: foodborne carcinogens of Pan African importance. Afr. Newsl. Occup. Health Saf. 2, 11-18.

Marnewick, J. L., van der Westhuizen, F. H., Joubert, E., Swanevelder, S., Swart, P. and Gelderblom, W. C. (2009): Chemoprotective properties of rooibos (Aspalathus linearis), honeybush (Cyclopia intermedia) herbal and green and black (Camellia sinensis) teas against cancer promotion induced by fumonisin $\mathrm{B}_{1}$ in rat liver. Food Chem. Toxicol. 47, 220-229.

Merrill, A. H. Jr., Schmelz, E. M., Wang, E., Dillehay, D. L., Rice, L. G., Meredith, F. and Riley, R. T. (1997): Importance of sphingolipids and inhibitors of sphingolipid metabolism as components of animal diets. J. Nutr. 127, 830-833.

Merrill, A. H. Jr., Wang, E. and Riley, R. T. (1993): Method of altering sphingolipid metabolism and detecting fumonisin ingestion and contamination. Official Gazette of the United States Patent and Trademark Office 1153, 384.

Mobio, T. A., Tavan, E., Baudrimont, I., Anane, R., Carratu, M-R., Sanni, A., Gbeassor, M. F., Shier, T. W., Narbonne, J. F. and Creppy, E. E. (2003): Comparative study of the toxic effects of fumonisin $\mathrm{B}_{1}$ in rat $\mathrm{C} 6$ glioma cells and p53-null mouse embryo fibroblasts. Toxicology 183, 65-75.

Otaka, M., Odashima, M. and Watanabe, S. (2006): Role of heat shock proteins (molecular chaperones) in intestinal mucosal protection. Biochem. Biophys. Res. Commun. 348, 1-5.

Placer, Z. A., Cushman, L. L. and Johnson, B. C. (1966): Estimation of product of lipid peroxidation (malonyl dialdehyde) in biochemical systems. Anal. Biochem. 16, 359-364.

Rao, P. N. and Engelberg, J. (1965): HeLa cells: effects of temperature on the life cycle. Science 148, 1092-1094.

Riley, R. T. and Voss, K. A. (2006): Differential sensitivity of rat kidney and liver to fumonisin toxicity: organ-specific differences in toxin accumulation and sphingoid base metabolism. Toxicol. Sci. 92, 335-345.

Riley, R. T., Hinton, D. M., Chamberlain, W. J., Bacon, C. W., Wang, E., Merrill, A. H. and Voss, K. A. (1994a): Dietary fumonisin $B_{1}$ induces disruption of sphingolipid metabolism in Sprague-Dawley rats: a new mechanism of nephrotoxicity. J. Nutr. 124, 594-603.

Riley, R. T., Voss, K. A., Yoo, H. S., Gelderblom, W. C. A. and Merrill, A. H. (1994b): Mechanism of fumonisin toxicity and carcinogenesis. J. Food Prot. 57, 638-645.

Rumora, L., Domijan, A. M., Grubisić, T. Z. and Peraica, M. (2007): Mycotoxin fumonisin B alters cellular redox balance and signalling pathways in rat liver and kidney. Toxicology $\mathbf{2 4 2}$, $31-38$.

Salminen, W. F., Richard, V. and Roberts, S. M. (1996): Induction of Hsp70 in HepG2 cells in response to hepatotoxicants. Toxicol. Appl. Pharmacol. 141, 117-123.

Salminen, W. F., Voellmy, R. and Roberts, S. M. (1998): Effects of N-acetyl cysteine on heat shock protein induction by acetaminophen in mouse liver. J. Pharmacol. Exp. Ther. 286, $519-524$.

Schroeder, J. J., Crane, H. C., Xia, J., Liotta, D. C. and Merrill, A. H. Jr. (1994): Disruption of sphingolipid metabolism and stimulation of DNA synthesis by fumonisin $\mathrm{B}_{1}$ : A molecular mechanism for carcinogenesis associated with Fusarium moniliforme. J. Biol. Chem. 269, $3475-3481$.

Sedlak, J. and Lindsay, R. H. (1968): Estimation of total, protein-bound, and nonprotein sulfhydryl groups in tissue with Ellman's reagent. Anal. Biochem. 25, 192-205. 
Thiel, P. G., Marasas, W. F. O., Sydenham, E. W., Shephard, G. S. and Gelderblom, W. C. A. (1992): The implications of naturally occurring levels of fumonisins in corn for human and animal health. Mycopathology 117, 3-9.

Tolleson, W. H., Dooley, K. L., Sheldon, W. G., Thurman, J. D., Bucci, T. J. and Howard, P. C. (1996): The mycotoxin fumonisin induces apoptosis in cultured human cells and in liver and kidneys of rats. Adv. Exp. Med. Biol. 392, 237-250.

Voss, K. A., Chamberlain, W. J., Bacon, C. W. and Norred, W. P. (1993): A preliminary investigation on renal and hepatic toxicity in rats fed purified fumonisin $B_{1}$. Nat. Toxins $1,222-228$.

Voss, K. A., Norred, W. P., Plattner, R. D. and Bacon, C. W. (1989): Hepatotoxicity and renal toxicity in rats of corn samples associated with field cases of equine leukoencephalomalacia. Food Chem. Toxicol. 27, 89-96.

Voss, K. A., Riley, R. T., Bacon, C. W., Chamberlain, W. J. and Norred, W. P. (1996): Subchronic toxic effects of Fusarium moniliforme and fumonisin $\mathrm{B}_{1}$ in rats and mice. Nat. Toxins 4 , 16-93.

Wallach, D. (1996): Suicide by order: Some open questions about the cell killing activities of the TNF ligand and receptor families. Cytokine Growth Factor Rev. 7, 211-221.

Wang, E., Norred, W. P., Bacon, C. W., Riley, R. T. and Merrill, A. H. (1991): Inhibition of sphingosine biosynthesis by fumonisins. J. Biol. Chem. 266, 14486-14490.

Weichselbaum, T. E. (1948): An accurate and rapid method for the determination of protein in small amounts of serum and plasma. Am. J. Clin. Pathol. 16, 40-43.

Wood, L. C., Jackson, S. M., Elias, P. M., Grunfeld, C. and Feingold, K. R. (1992): Cutaneous barrier perturbation stimulates cytokine production in the epidermis of mice. J. Clin. Invest. 90, $482-487$.

Yoo, H. S., Norred, W. P., Showker, J. and Riley, R. T. (1996): Elevated sphingoid bases and complex sphingolipid depletion as contributing factors in fumonisin-induced toxicity. Toxicol. Appl. Pharmacol. 138, 211-218.

Yoo, H. S., Norred, W. P., Wang, E., Merrill, A. H. and Riley, R. T. (1992): Fumonisin inhibition of de novo sphingolipid biosynthesis and cytotoxicity are correlated in LLC-PK cells. Toxicol. Appl. Pharmacol. 114, 9-15.

Zieglerheitbrock, H. W. L., Kafferlein, E., Haas, J. G., Meyer, N., Strobel, M., Weber, C. and Flieger, D. (1992): Gangliosides suppress tumor necrosis factor production in human monocytes. J. Immunol. 148, 1753-1758. 